\title{
Effective Classroom Management
}

\author{
Azlin Norhaini Mansor ${ }^{1}$, Wong Kim Eng ${ }^{2}$, Mohamad Sattar Rasul ${ }^{1}$, Mohd Izham Mohd Hamzah ${ }^{1}$ \&
}

Aida Hanim A. Hamid ${ }^{1}$

${ }^{1}$ Universiti Kebangsaan Malaysia, Bangi, Malaysia

${ }^{2}$ Open University Malaysia, Kuala Lumpur, Malaysia

Correspondence: Azlin Norhaini Mansor, Universiti Kebangsaan Malaysia, Bangi, Malaysia. E-mail: azlinmansor@ukm.my

Received: May 19, 2012 Accepted: May 28, 2012 Online Published: July 31, 2012

doi:10.5539/ies.v5n5p35 URL: http://dx.doi.org/10.5539/ies.v5n5p35

\begin{abstract}
This paper attempts to explore and identify the characteristics of an effective teacher who teaches English as a second language to 10 year old students from different ethnics, various social economic background and multi-level language ability, at a private primary school in Malaysia. The study focused on classroom management using a case study methodology where data was collected using both interviews and classroom observations. The findings concur with previous literature reviews on effective teacher models whilst providing in-depth details on what transpires during classroom activities, thus clarifying further the meaning of effective classroom management. The implications of this study suggest the need to include six new classroom management behaviours of an effective teacher. Further research is warranted to help policy makers and school administrators in identifying the significance of these behaviours for the selection and training of future teachers.
\end{abstract}

Keywords: effective teacher, classroom management, teacher training

\section{Introduction}

What does it take to be an effective teacher? While aspiring teachers can increase their knowledge and develop their skills, their intrapersonal and interpersonal character, in addition to their spiritual beliefs, are likely to remain the same (Cantor, 1990). As noted by Cantor, "Having is not the same as doing." So, while teachers can develop both knowledge and skills through experience and training, without the ability and the disposition to make use of them, very little will happen. Thus, he concluded that it is very difficult to identify these effective teacher characteristics because personal traits are rooted in feelings and beliefs, which we can neither observe directly nor assess using simple questionnaires (Ostorga, 2003). These setbacks make the characteristics difficult to identify.

Nevertheless, policy makers, administrators, teacher educators and aspiring teachers would benefit significantly from knowing the characteristics of effective teachers, as this knowledge would likely improve the quality of the field. New teachers and those at a crossroads in their career would also benefit if they could confirm that the interpersonal and intrapersonal beliefs they possess are those demanded by the field. With these goals in mind, this article aims to share the findings of an empirical study on the key characteristics teachers need to excel in their job, focusing on classroom management.

\subsection{Background}

The Malaysian National Education Philosophy states that:

"Education in Malaysia is an on-going effort towards further developing the potential of individuals in a holistic and integrated manner, so as to produce individuals who are intellectually, spiritually, emotionally and physically balanced and harmonic, based on a firm belief in and devotion to god..."

National Education Blueprint 2006-2010: ix

Thus, as educators, our main responsibility is to produce such students and to prepare them to face myriad world challenges upon graduation. Apart from parents, the teacher is the next crucial factor, who patiently, year in and year out, goes into the classroom to teach and mould the children under his or her care. Some students even 
study under the same teacher for a number of years. Thus comes the famous quote "A teacher affects eternity; he can never tell where his influence stops," by Henry Brooks Adams (1838-1918:Chp. 20). Therefore, the power of teachers to influence students cannot be denied.

What sort of influence is crucial? What makes one teacher effective and another ineffective? There are definite reasons to why a teacher is effective. A study by Johnson (1980) determined four key characteristics that correlated with teacher effectiveness: having sound knowledge of subject matter; taking personal interest in each student; establishing a caring and warm atmosphere; and showing enthusiasm with students. Other studies have identified several characteristics of an effective teacher, which include enthusiastic, effective communicator, adaptable to change, lifelong learner, competent, accepting of others, patient, organized, hardworking, and caring (Glenn, 2001; Mujis, 2005: Malikow, 2006; Goe, 2007; Daniel, 2010; Korthagen, 2004, Vallance 2000); Hattie 2003) defines excellent teachers, effective teachers or expert teachers as teachers who are able to teach and at the same time create a learning environment within the class to the point that the students enjoy learning and love to learn under that teacher. Teachers are basically the pillars who are responsible for the success or failure of our educational system. As a result, any research findings that could improve the system are worth sharing.

The purpose of this study is to discover what transpires in the classroom and to identify the characteristics of a well-known teacher who teaches English as a second language to 10-year-old students from different ethnic and socioeconomic backgrounds and with varying language abilities. This teacher makes such an impact that her students do not give the school administration difficult discipline issues and instead have such motivation that they excel in the process.

\section{Literature Review}

In a study conducted by Hattie (2003), besides students themselves (50\%), teachers account for 30 percent of the influencing factor in students' achievement, followed by home environment (5-10\%), schools (5-10\%), and peer effects $(5-10 \%)$. The teachers' variance is important, as it is what teachers know, do and care that make the difference in this learning equation.

Teachers therefore are an important asset in schools, and the greater the ability, all the more effective the teachers will be. We should focus on the greatest source of variance that can make the difference and have powerful and sensationally positive effects on learners. The educational community should direct its attention to higher quality teaching, and develop higher expectations that students can meet appropriate challenges that occur once the classroom door is closed (Hattie, 2003).

Witcher, Onwuegbuzie, and Minor, L.C. (2001) suggested six themes for the characteristics of effective teachers. The author listed the themes as student centeredness, enthusiasm for teaching, ethical values, classroom and behaviour management, teaching methodology and knowledge. On the other hand, Hattie (2003) presented a different perspective on the characteristics of an effective teacher as someone who knows their subject matter well, is able to identify essential representations of their subject, can guide and motivate learning through classroom activities, can monitor learning and provide effective feedback, can attend to attentive attributes, and can influence student outcomes.

The power of effective teachers cannot be underestimated, as proven in a study conducted by Darling, Chung, and Freflow (2002). Darling et. al. (2002) study concludes that teacher effectiveness was significantly related to student performance, more so than factors such as class size. Furthermore, the effect appeared to be cumulative and additive, in that students taught by ineffective teachers for consecutive years do significantly worse in terms of both gains and achievement compared to peers who were assigned to effective teachers for consecutive years. The weight of influence of effective teachers is undeniably powerful.

As there are various and multiple factors involving teacher effectiveness in this discussion, we categorized all the running themes into three broad categories. The three categories are teacher role, subject matter and classroom management.

\subsection{Teacher Role}

What the teachers do in the class, their values, their personality, their conduct in class, their manner of handling the class, all come into play during the lesson. There is no one particular ingredient that is crucial for making an effective teacher. It's a combination of factors.

The first is how the teacher treats the students. Effective teachers must respect them as learners and people, and demonstrate care and commitment (Hattie, 2003). These are attributes of expert teachers. By having such respect, they can recognize possible barriers to learning and can seek ways to overcome these barriers. Second, teachers also need to show and communicate their enthusiasm, for such displays will produce an immediate increase in 
student motivation. By focusing their instructional goals on the acquisition of mastery rather than competitive and comparative goals, superior teachers prompt students' intrinsic motivation to become the force behind learning (Heller \& Sottile, 1996). If the teacher is not interested in the material he/she is presenting, the outcome will be student boredom and dislike for the subject as well. How many times have we heard students say they excel because of this teacher or a student likes a subject because of a teacher? This is where grave mistakes are made when teachers are trained in subjects they do not like and they take up that offer because there is no other option of jobs or option of subjects offered (Hattie, 2002).

In research done by Malikow (2006), exhibiting a caring attitude is the third most frequently cited characteristic of an effective teacher, together with being interested in students. One cannot be caring and yet be uninterested in their students because these two traits work hand in hand. Vallance (2000) defines this as a personal commitment to students because they love them as individuals, and this commitment moves them to act for their students' benefit. Without this commitment or this passion, teaching can easily become a mundane routine, performed solely to make a living. Many teachers fall into this trap, especially after many years in service (Chua, 2008).

On the other hand, Sosu \& Gray (2011) and Edward and Donald (2011) highlighted the importance of epistemic beliefs - beliefs about the nature of knowledge and knowing - and their role in garnishing teaching competence. They claimed that only beliefs about 'source of knowledge' significantly predicted teaching competence, whilst entry qualifications, instructional preference and the other epistemic dimensions were not significant predictors of teaching competence.

\subsection{Subject Matter}

Goe (2007) suggested that the expert teacher possesses knowledge that is more integrated. Such teachers combine new subject matter content knowledge with prior knowledge; can relate current lesson content to other subjects in the curriculum; and make lessons uniquely their own by changing, combining and adding to them according to their students' needs and the teacher's own goals.

Hattie (2003) further added that expert teachers can spontaneously relate what is happening to these deeper sets of principles; can quickly recognize sequences of events occurring in the classroom that in some way affect the learning and teaching of a topic; are more opportunistic and flexible in their teaching; are more adept at anticipating problems and then improvising; are skillful in keeping the lesson on track and accomplishing their objectives; and allow student questions and comments as springboards for discussion. In a different study, it was noted that effective teachers are also able to explain complicated material well and do it creatively (Malikow, 2006).

\subsection{Classroom Management}

The discussion on classroom management includes behaviour management because both managerial traits cannot always be distinguished, especially when the lesson is being carried out.

Earlier studies on classroom management that focusing on students' sense of belonging in school contexts have found that a strong sense of belonging can result in positive outcomes, including academic motivation, a sense of efficacy, a liking for school, and a sense of emotional well-being (Goodenow, 1993; Wentzel, 2003). A strong sense of belonging has been associated with a desire to learn and an increase in understanding, whereas a lack of belonging has been associated with negative academic outcomes such as truancy and withdrawal from school.

Schackne (2007) also noted that prompt feedback contributes to increased motivation and retention, and that retention is increased when the material is made relevant to students' lives. Furthermore, students' motivation to learn increases when they are granted a decision-making capacity regarding the direction of the class, which is also positively related to student autonomy (Heller \& Sottile, 1996). On another note, effective teachers should set tasks that are challenging with reasonable expectations (Malikow, 2006). All these would lead to active learning as put forth by Hattie (2003), with expert teachers preferring to involve students in their learning rather than talking most of the time.

Effective teachers also recognize that students have 'unique learning styles' (Sadler-Smith, 1996). This understanding calls for different and interesting approaches and teaching methods in the classroom. Mujis (2001) suggests that teaching strategies need to be varied according to different learning needs of students. Teaching should also be interactive in that teachers should involve students by asking relevant questions and giving prompt feedback. Teachers also need to have an active role in the teaching and learning in the classroom. Above all, effective teachers should be able to detect when students are learning or motivated to learn or are losing focus or interest in the topic presented on that day. In such a scenario, they are able to realign the focus of the 
students through participation or through showing that the teacher cares and is aware of the students' feelings. It is an approach, according to Forsyth and McMillan (1991), that leads students to feel valued in class.

Finally, it was Hattie's (2002) remark regarding classroom management that has made a significant impact on the scope chosen in this study. He concludes that learning outcomes are directly related to the learning environment within the classroom created by the teacher due to the fact that the processes of learning that they foster are by far the more powerful.

\section{Methodology}

Consistent with case study methodology, observation, interviews and document analysis were chosen as the best means of collecting the data required for an educational case-study research setting (Merriam, 1997). Five full-day classroom observations were video recorded together with the field notes, and a total of 10 interview hours were transcribed. Observation data on the process of teaching and learning in the classroom was triangulated with semi-structured interviews with the teacher herself, four school administrators, five colleagues and 21 (all) of the teacher's 10 year old students.

This particular teacher was chosen as the sole sample because of her well-known credibility as the teacher in the school who need not raise her voice in class for anything. She always receives good feedback from both students and parents, and most important, she has an excellent track record of class discipline. To begin with, this teacher began her career as a qualified English teacher at various government secondary schools in Malaysia since 1968. After she retired in 1995, she decided to join a private primary school, and this move made a significant impact on her, as she had never taught, trained nor handled primary school children. Her modesty and perseverance turned her into one of the best teachers the school has ever encountered. Her reputation as a good teacher has never left her since the day she started teaching in the school. In recent years she has made a significant contribution in turning her class around, and the class has won the monthly cleanliness trophy for almost an entire year, missing only twice. The class was also noted for its outstanding discipline during line-up after break time. Most important, she is highly respected not only by the students but also by the parents. Furthermore, her views and opinions are always sought out by colleagues and school administrators.

\section{Findings and Discussions}

The findings are discussed under the three broad categories as in the literature review. Under the 'teachers' role' category, the teacher observed is noted to have respect for her students in the class. She calls them by name and she knows her students well. She is able to recognize the weak, the quiet, and those who seem to dominate classroom discussion most of the time. She constantly reminds the class that she would like the weaker ones to try. She always looks around for students not putting up their hands and encourages them to answer. By doing so, she instils confidence in the weaker ones, at the same time conveying a sense of sharing, patience and understanding to the whole class.

She demonstrates a strong commitment towards her students. This is noticed during the first observation, when she reminded the class about being the best and disciplined even when she is not with them. This is known as vision setting, where a teacher gives her students a focus or a goal to achieve. In the fifth observation, she encourages them not to admit defeat even though they lost the cleanliness trophy that week. She also told them she likes their spirit of not giving up. Her students that were interviewed mentioned her not getting angry when they fail but instead encouraging thus motivating them to carry on.

“She supports us. She encourages us to be better. If we don't win or when we fail a subject, she doesn't scold us; she tells us to try again. She doesn't get mad."

"She doesn't get angry. She's kind and patient. Even if she gets angry, she doesn't (student shows an angry face). She doesn't spank."

That commitment was also shown when she returned from her medical leave and asked the class how they were doing. She then listened to her students' report, an indication that she cares for them. Sharing the students' stories shows she cares; at the same time she is not afraid to share her feelings and thoughts. This sharing behaviour was felt by the students and made them ask her why she was absent and what made her sick. Commitment promotes caring that manifests in sharing of information, which finally produces the spirit of caring. All these components show her interest in the students' well-being. The spirit of sharing and caring is the energy of enthusiasm that she displays in her quiet manner.

The teacher knows her lessons well, which we feel would have demanded some amount of time spent in preparation. There was not a dull moment in all of the five observations; each lesson was creatively prepared. The teaching methodologies were also varied. There was storytelling using herself as the main topic and real-life 
scenarios relevant to the students. She also used students as her topic of discussion or in bringing out a point related to the lesson, real objects such as fresh fruit for the reading class, teaching aids like the alphabet chart, handouts, the classroom plants, question and answer, drills, repetition, and the list continues. Her classes did not leave any room for the students to create unwanted issues or engage in bad behaviour during lesson.

She combines prior knowledge of the students, linking this knowledge to the present moment and knowledge about other topics. For example, how to choose a 'good' durian, taking the students to the market to learn about local fruits, using the colloquial term 'heaty' to mean 'feeling hot,' discussing experiences on 'balik kampong' or going back to your home town, using the Malay language to explain difficult terminology, using real plants to teach science, and many others. All these show her creativity in lesson presentation and in using the situations that arise in class. She also uses the students' replies or questions as a springboard to teach the lesson on values or the contents of the topic for that day. Her students also concluded that the class is lively.

She knows how to keep the class focused on what she is teaching. Whenever she comes into the classroom, the students automatically remove the things on their desk and keep them inside their bags or inside their desk drawer. Having things on the desk can serve as a distraction, so she repeats this teaching every time she sees students with cluttered desks.

She constantly checks with her students as to whether they understand her lesson or not. When they face any difficulty in understanding the text or a word, she is always willing to explain. This behaviour was noted in the interviews too. "She helps us with revision and difficult words. Usually she will tell us stories." When asked how telling stories helps, the reply was; "So we can understand what she wants us to do." Her student also mentioned that she helps them with their homework and difficult words.

She does not complain or reprimand, nor would she chide her students even if they ask her 'silly questions.' She simply makes sure that her students understand what she has taught them. This demonstrates her passion and her willingness to go beyond her ways in ensuring that transfer of knowledge has occurred. It also shows her readiness and flexibility in adapting her teaching methodologies to the student's style of learning.

We also noted that in all the classroom teaching and learning observations, the tasks given were challenging and appropriately designed to suit the student age level and ability, so that each student can meet the objectives as listed in the lessons' learning outcome. This shows that the teacher has done a lot of preparation prior to the teaching time.

Her lessons were organized. She always starts with a set induction to gauge the students' attention, then proceeds to introduce the lesson topic for that day with various styles. She then reinforces the topic with various activities and drills as demonstrated in all the observations. Her final lesson is written work, which usually becomes their homework.

Another prominent feature in all the observations is her spirit of encouragement, be it praises for answering, commendations for getting good marks, or passing simple words of encouragement. She does not seem to have much negativism in her class. One student says she always "...says nice thing to us". She has an inbuilt quality that runs when she is in her class and likely when she is outside of her class. During the interview, she explained the power of encouragement. Her encouragements make the students feel valued and also make them feel that they belong to the class. She is a great motivator as proven by Student B, who would continue to be the best even as she moved beyond this teacher; "Yes, because she tells us we must be the best even though she's not there. Yes, be together as the best."

Instead of penalising her homework dodger, she would praise him when the student finally handed in his homework to her. And when the same student did not pass up his work during the fifth observation, she attended to him one-on-one and helped him finish the work immediately after class. There was no shouting or yelling, nor would she send the student out of the class. She was in control. She embodied the Chinese saying "give the boy 'face' so as not to embarrass him."

Though the competitive spirit was invoked during her lessons as well as in the distribution of games, she used competitiveness as points for rewards. Her rewards were abundant and generous. Pizzas, squash racquets, ice-creams, and sweets, were some of the prizes mentioned; "She gives us lots of presents; sweets, Pizza Hut, Dominoes pizza. She also uses her own money to buy stuff for the class. She also gives us things she doesn't want."

Points were also given for doing work on time, being honest, unusual answers and also group work rewards. Points were also used as her method of discipline. "When she wants to teach us from our wrong doing, she just minus marks, millions of marks. The most is grounding." (Grounding is taking away the privilege of play time 
during break and lunch time.)

Her effective teacher characters were also noted when she does immediate remedial, gives immediate feedback, and does correction during almost every lesson. She always gives extra information on her subject matter. It is noted that in awarding points she makes use of her students' opinions, demonstrating the skill of allowing student autonomy.

Below we will further discuss other characteristics and behaviour of this teacher that have not been or are seldom discussed in the literature on effective teachers.

First, she demonstrated her capability in using unplanned situations or recognizing helpful events as part of the lesson to remind the students about values. As Hattie (2003) mentioned, expert teachers are able to deal with the multidimensionality of the classroom. In the classroom, events cannot be predicted. It fascinates us that this teacher knows when to make use of those events and turn those moments into a teaching point. Recognizing helpful events requires a conscious effort to make those situations worthwhile. We realized that it is a unique ability that deserves deeper probing to understand how she manages to be conscious of such events while simultaneously managing the lessons as well.

From the interviews with her, her students and colleagues, we argued that the special ability in recognising helpful events is due to the fact that she loves teaching; she loves the children, the school and, most of all, she loves her profession as a teacher. To love one's profession as a pre-requisite to being effective is seldom discussed in the literature. This finding has in fact given insight into what defines 'teacher's love for teaching.' What type of behaviour or characteristics denote a 'loving thy profession? Thus, we would strongly suggest that future research is needed to look deeper into this aspect. We believe that 'loving thy profession' characteristics could be an important predictor of an effective teacher. Such an endeavour could further determine whether 'love for teaching' is inert, nurtured or taught. It could also help policy makers and school administrators in deciding whether to make it into an important criterion for future teacher selection, thus solving the issue on the importance of loving your profession versus going into the profession because of economic circumstances.

Second would be her helpfulness, which went beyond the classroom hours. This was mentioned by the first interviewee, that she spot checks her class on cleanliness.

"She helps us a lot. She helps us do our duty, like sometimes she sweeps the floor; and arranges the books during break and lunch time. She will do that together with us after class. Sometimes she also spot checks after school. She also checks the tables, the floor (clean or not clean), and arranges the tables."

The teacher explains that in doing so, she was inculcating team spirit among her students and that she is also a part of the team. Indirectly, her behaviour promotes togetherness, which strengthens kinship among the students.

Third is her effort in enhancing the physical appearance of the class. The windows were lined with pastel coloured butterflies so the students would not be distracted by the view outside. One of the door mirrors (small, rectangular shape) was covered with a semi large sheet of blue colour, so giving the room a calm feeling and also cutting down on the sunlight. There were two large green leafy plants in the front of the classroom. The trophy was kept at the far left end with a vase of flowers beside it. The notice boards were decorated with bright colours behind them, and the boards were divided for subjects and announcements. The boys and girls group marks were posted there for everyone to see. We noticed that everything in the classroom was decorated with the purpose of making the classroom bright yet comfortable and pleasant.

Fourth is her endless practice of the art of 'scaffolding.' Scaffolding means the poles and planks used to build scaffolds for construction work so that the workers can do the necessary labour. In this context, scaffolds means 'to provide support.' (McNeil, 2012). We acknowledged this teacher's frequent use of her skills and the art of scaffolding in her lessons and realized its impact on her students. She gives clues when the child gets stuck in providing answers and provides more clues until s/he gets the answer. She did it so tactlessly, and this made the students feel it was all their own doing.

The fifth notable point in her teaching was the way she weaves values into her teaching. She indirectly teaches leadership qualities, encourages thinking skills, and incorporates values and school rules which she interweaves into her lessons. She delicately made suggestions to the students, giving examples, and surprisingly the students were able to pick up her thoughts.

Last but not least: her sense of humour is very natural, and this makes her class lively and interesting. Apart from bringing humour into the classroom, she constantly reminds the students to be honest and helpful and to respect each other and be on time. Bringing humour and repeating reminders about good behaviour are two criteria seldom discussed in the reviews. The reminders show that she has laid down some rules from the very beginning 
of the year, and the class knew exactly what she wanted. This makes her job easier and the lesson flow continuously. This might suggest that creating class rules and class boundaries as part of the characteristics of an effective teacher.

She is a selfless teacher. Her goal was her student's achievements, not hers. She is like the burning candle: She burns herself for the light of others, a trait not mentioned in the readings. When asked to describe her character, her students' quick response was mostly, "She is the best;" "She is wonderful;" "She is awesome;" "She is great;" "I love her." She definitely has made a deep impact on her students' lives. She is exactly as described by Jung;

'One looks back with appreciation to the brilliant teachers, but with gratitude to those who touched our human feelings. The curriculum is so much necessary raw material, but warmth is the vital element for the growing plant and for the soul of the child.'

Carl Gustav Jung (1875-1961); 144

\section{Conclusion}

An effective teacher would demonstrate all the skills listed in the three broad categories. However we would like to propose another six more notable characteristics of an effective teacher: (i) loving the profession; (ii) going beyond the lesson time; (iii) creating a suitable yet comfortable physical classroom environment; (iv) practising the art of scaffolding (v) weaving values, leadership and thinking skills into the lesson and (vi) creating class rules and boundaries through repetition and humour. Though these findings are based on one teacher, they are justifiable by the rigorous data collection method used and deserve follow-up. Thus, we believe that further research is inevitable to enable comparisons to be made, and such findings would be more conclusive in developing a complete list of the characteristic of an effective teacher, specifically on classroom management.

\section{References}

Cantor, N. (1990). From thought to behaviour: "Having" and "doing" in the study of personality and cognition. American Psychologist, 45(6), 735-50.

Chua, S. B. (2008). Thoughtful teaching-The spirit of learning. CDTLink, 12(1), 5. Retrieved from http://www.cdtl.nus.edu.sg/link/Jul2009/li3.html

Darling L., Chung, R., \& Freflow, F. (2002). Variation in teacher preparation. Journal of Teacher Education, 53(4), 286-302. Retrieved from: http://dx.doi.org/ 10.1177/0022487102053004002

Daniels, E. (2010). Creating motivating learning environments: What we can learn from researchers and students. English Journal, 1, 25-29. Retrieved from http://4plc.edublogs.org/files/2010/11/motivation118r87q8

Edward M. S., \& Donald, S. G. (2011). Investigating change in epistemic beliefs: An evaluation of the impact of student teachers' beliefs on instructional preference and teaching competence. http://dx.doi.org/ 10.1016/j.ijer.2012.02.002

Forsyth, D. R., \& McMillan, J. H. (1991). Practical Proposals for Motivating Students. In Menges, R. J., \& Svinicki, M. D., eds. College Teaching: From Theory to Practice. New Directions in Teaching and Learning, $45,53-65$

Glenn, R. E. (2001). Admirable teaching traits. Teaching for excellence. Spartansburg, SC: Author. Retrieved from www.education-world.com/a_curr/curr387.shtml

Goodenow, C. (1993). Classroom belonging among early adolescent students: relationships to motivation and achievement. Journal of Early Adolescence, 13, 21-43.

Goe, L. (2007). The link between teacher quality and student outcomes: A research synthesis. Retrieved from http://www.ncctq.org/publications/LinkBetweenTQandStudentsOutcomes.pdf

Hattie, J. (2003). Teachers make a difference. What is the research evidence? International Journal of Educational Research, 37, 449-481.

Hattie, J. (2002). Classroom composition and peer effects. School of Education, University of Auckland. http://dx.doi.org/ -10.1016/ S0883-0355(03)00015-6

Heller, D., \& Sottile, J. M. (1996). Another look at student motivation: A Qualitative Study. Retrieved from http://eric.ed.gov/PDFS/ED398524.pdf

Henry Adams. (1907). The Education of Henry Adams. Boston: Houghton Mifflin (1961). Retrieved from http://en.wikiquote.org/wiki/Henry_Adams\#The_Education_of_Henry_Adams_.281907.29 
Jung, C. G. (1981). The Development of Personality (Collected Works of C.G. Jung Vol.17). Princeton University Press (October 1, 1981)

Johnson, M. (1980). Effective teaching as perceived by teachers and principals in selected Indiana school corporations. Retrieved from www.bsu. edu/libraries/virtualpress/student/dissertations/author_list.asp

Korthagen, F. (2004). In search of the essence of a good teacher: towards a more holistic approach in teacher education. Retreived from http://dx.doi.org/10.1016/j.tate.2003.10.002

Malikow, M. (2006). Effective teacher study. National Forum of Education Journal -Electronics, 16(3E), 2005-2006. Retrieved from http://www.nationalforum.com/Electronic\%20Journal\%20Volumes/Malikow\%2C\%20Max\%20Effective\% 20teacher\%20Study.pdf

McNeil, L. (2012). Using talk to scaffold referential questions for English language learners. An International Journal of Resesarch and Studies. Teaching and Teacher Education, 28(3), 396-404.

Educational Planning and Research Division. (2006). National Education Blueprint 2006-2010: Ministry of Education Malaysia.

Muijs, R. D., \& Reynolds, D. (2005). Effective teaching. London: Sage Publishing.

Muijs, D. (2001). Effective mathematics teaching: Year 2 of a research project. Retrieved from http://highreliability.co.uk/Files/Downloads/Effectiveness/DM2002a.pdf

Ostorga, A. N. (2003). The role of values in the development of dispositions. Paper presented at the Second Annual Symposium on Educator Dispositions, 20-21, in Richmond, Kentucky, USA

Schackne, S. (2007). Leveling your students: The common sense approach in DevelopingTeachers.Com. Retrieved from http://www.schackne.com/ Goodteacher.htm

Sadler-Smith, E. (1996). Learning styles: a holistic approach. Journal of European Industrial Training, 20(7), 29-36.

Merriam S. B. (1997). Qualitative Research and Case Study Applications in Education: Revised and Expanded from Case Study Research in Education. Jossey-Bass; 2 edition.

Sosu, E. M., \& Gray, D. D. (2011). Investigating change in epistemic beliefs: An evaluation of the impact of student teachers' beliefs on instructional preference and teaching competence. Retrieved from http://dx.doi.org/10.1016/j.ijer.2012.02.002

Vallance, R. (2000). Excellent teachers: Exploring self constructs. Role and personal challenges. Paper presented at the Australian Association for Research in Education (AARE), Conference. Retrieved from http:// www.aare.edu.au/00pap/val00341.htm

Wentzel, K. R. (2003). Motivating Students to Behave in Socially Competent Ways. Theory Into Practice, 42(4), 319-326, Autumn 2003. Retrieved from http://dx.doi.org/10.1353/tip.2003.0054

Witcher, A. E., Onwuegbuzie, A. J., \& Minor, L. C. (2001). Characteristics of effective teachers: Perceptions of preservice teachers. Research in the Schools, 8(2), 2001, 45-57. 